\title{
Seed quality of common bean accessions under organic and conventional farming systems ${ }^{1}$
}

\author{
Diego Medeiros Gindri ${ }^{2}$, Cileide Maria Medeiros Coelho², \\ Clovis Arruda Souza ${ }^{2}$, Isaac Heberle ${ }^{2}$, Heitor Amadeu Prezzi ${ }^{2}$
}

\section{ABSTRACT}

Agrobiodiversity is essential for a sustainable food production, and the knowledge of the potential characteristics of landrace seeds may prompt farmers to adopt the habit of seed conservation for this species. This study aimed at categorizing landrace and commercial common bean (Phaseolus vulgaris L.) accessions, according to the physiological quality (viability and vigor) of seeds produced in the field, during two growing seasons, under organic and conventional farming systems. Germination percentage, field emergence, electrical conductivity, accelerated aging, cold test and seedling length were assessed. The landrace bean accessions exhibit diversity in the physiological seed quality, in terms of their viability and vigor. No differences were observed between the farming systems, in relation to the physiological quality of the seeds produced. The categorization of landrace common bean accessions allows to identify those with superior physiological seed quality.

KEYWORDS: Phaseolus vulgaris L.; agrobiodiversity; seed vigor; seed viability.

\section{INTRODUCTION}

Ever since the beginning of agriculture, managing the diversity and crop species and varieties has been a central element in the sustainability of farming systems. To ensure that food production achieves its sustainability goals, recovering local, traditional or landrace varieties and increased autonomy by farmers are considered good practices in meeting the demand for propagation materials and selecting varieties to maintain genetic diversity (Brasil 2008). Preserving and maintaining the genetic diversity of species are also considered environmental services, being strategic for a farmer in search of sustainability (Gliessman 2000, Penteado 2010).

\section{RESUMO}

Qualidade de sementes de acessos de feijão sob sistemas de cultivo orgânico e convencional

A agrobiodiversidade é indispensável para a produção de alimentos de forma sustentável, e o conhecimento das características potenciais das sementes de acessos crioulos pode auxiliar na retomada, por parte dos agricultores, do hábito de conservação de suas sementes. Objetivou-se categorizar os acessos crioulos e comerciais de feijão (Phaseolus vulgaris L.) pelas características da qualidade fisiológica (viabilidade e vigor) de sementes produzidas em campo, em duas safras agrícolas, sob cultivos orgânico e convencional. Foram avaliados o percentual de germinação, emergência a campo, condutividade elétrica, envelhecimento acelerado, teste de frio e comprimento de plântulas. Os acessos crioulos de feijão apresentam diversidade na qualidade fisiológica das sementes, pelas suas características de viabilidade e vigor. Não foram observadas diferenças entre os sistemas de produção, na qualidade fisiológica das sementes produzidas. A categorização dos acessos crioulos de feijão permite indicar quais deles possuem qualidade fisiológica superior das sementes.

PALAVRAS-CHAVE: Phaseolus vulgaris L.; agrobiodiversidade; vigor de sementes; viabilidade de sementes.

The federal law 10711/2003, which regulates the production and commercialization of seeds and seedlings in Brazil, allows farmers to keep part of their common bean production to use as seed in the next crop (Brasil 2003). Keeping their own seeds allows farmers to control the central factor of production and ensure better plant adaptation to the environment in which they are produced, as well as guaranteeing, in the case of organic farming, that crops are produced under agroecological conditions. Validating agroecological farming technologies allows families to achieve more autonomy, which contributes to the development of local family farming (Altemburg et al. 2013).

Whether in conventional or organic farming, the production of seeds to keep on one's property 
does not follow the same criteria of conventional seed production, which is subject to rigorous quality control involving monitoring production fields, inspections during the crop cycle and laboratory analyses to verify quality. However, the seed selection to store at the farm cannot be only visual and should include information on quality characteristics.

The wide diversity found in landrace common bean (Phaseolus vulgaris L.) accessions, in terms of morpho-agronomic traits (Rodrigues et al. 2002, Coelho et al. 2007 and 2010a, Pereira et al. 2009), technological quality (Coelho et al. 2008, Bordin et al. 2010, Zílio et al. 2014), nutritional quality (Pereira et al. 2011) and physiological seed quality (Coelho et al. 2010b, Michels et al. 2014), indicates that they may be characterized by their physiological seed quality characteristics.

Physiological traits, such as seed vigor, are influenced by changes in chemical composition, primarily soluble protein, starch and soluble sugar content (Henning et al. 2010). The chemical composition of seeds, in turn, is affected by environmental conditions during seed formation, i.e., the growing practices adopted, as well as by genetic factors, which vary between different species and cultivars of the same species (Nedel 2003). As such, it is important to characterize the physiological potential of seeds produced under organic and conventional farming systems, in order to determine the response of each accession, in terms of the physiological quality of seeds produced using different management practices.

The knowledge of the potential characteristics of landrace accessions under organic and conventional farming systems may help farmers to conserve seeds and increase the use of these genetic resources (Coelho et al. 2007), broadening the possibility of managing and conserving agrobiodiversity.

This study aimed at categorizing landrace and commercial common bean accessions according to the physiological quality (viability and vigor) of seeds produced in two growing seasons, under organic and conventional farming systems.

\section{MATERIAL AND METHODS}

The study was conducted in the field, at the experimental station (27023' $14.37^{\prime}$ 'S and $51^{\circ} 13^{\prime}$ '0.32'W) of the Empresa de Pesquisa Agropecuária e Extensão Rural de Santa Catarina (Epagri), in Campos Novos,
Santa Catarina state, Brazil, and seed analyses were performed at the Seed Analysis Laboratory of the Universidade do Estado de Santa Catarina (UDESC).

The seeds assessed were produced in two growing seasons, at the same time and place, under organic and conventional farming systems, from November 2011 to February 2012 (growing season 1) and from November 2012 to February 2013 (growing season 2). The 26 common bean germplasm accessions (Table 1) from the active germplasm bank of UDESC used in the experiment were selected based on genetic diversity characteristics associated with morpho-agronomic traits, technological common bean quality and physiological seed potential (Coelho et al. 2008 and 2010a, Pereira et al. 2009).

The seed production experiment was conducted in the field, using a randomized block design, with three replications, in plots of four three-meter-long rows, with 15 seeds per meter. Organic management used species of white oat (Avena sativa L.) and

Table 1. Identification and origin of the common bean (Phaseolus vulgaris $\mathrm{L}$.) accessions used in the experiment.

\begin{tabular}{llll}
\hline Accession & Name of origin & \multicolumn{1}{c}{ Provenance } & \multicolumn{1}{c}{ Color } \\
\hline BAF 03 & Manchinha & Palmitos/SC & Cream \\
BAF 04 & Amendoim Lages Lages/SC & Red \\
BAF 07 & Preto Lages & Lages/SC & Black \\
BAF 13 & Taquara & Caxanbú do Sul/SC & Black \\
BAF 23 & Preto Chapecó & Chapecó/SC & Black \\
BAF 36 & Rasga & São José do Cerrito/SC Black \\
BAF 42 & Vagem Branca & Capão Alto/SC & Black \\
BAF 44 & Vermelho & Capão Alto/SC & Red \\
BAF 46 & Sem nome & Lages/SC & Black \\
BAF 47 & Preto (Precoce) & Piratuba/SC & Black \\
BAF 50 & Carioca Brilhante & Lebom Régis/SC & Cream \\
BAF 55 & Preto & Cunha Porã/SC & Black \\
BAF 57 & Preto & Cunha Porã/SC & Black \\
BAF 60 & Preto 60 dias & Lebom Régis/SC & Black \\
BAF 68 & Vermelho & Lagoa Vermelha/RS & Red \\
BAF 75 & Serrano & Formigueiro/RS & Black \\
BAF 81 & Black 70 dias & Lebom Régis/SC & Black \\
BAF 84 & Carioca Rosado & Pinheiro Machado/RS & Cream \\
BAF 97 & Charque & Iraí/RS & Black \\
BAF 102 & México 309 & Goiânia/GO & Black \\
BAF 108 & Branco & Recife/PE & White \\
BAF 110 & SCS 202 Guará & Lages/SC & Cream \\
BAF 112 & IPR 88 Uirapuru & Lages/SC & Black \\
BAF 115 & BRS Valente & Lages/SC & Black \\
BAF 120 & Roxinho & Lages/SC & Purple \\
BAF 121 & IAPAR 81 & Lages/SC & Cream \\
\hline BAF $~$ & & & Se UDC ave \\
\hline
\end{tabular}

BAF $=$ number at the UDESC active germplasm bank collection, in the Santa Catarina state, Brazil. BAF 110 (SCS 202 Guará), BAF 112 (IPR 88 Uirapuru), BAF 115 (BRS Valente) and BAF 121 (IAPAR 81) are commercial cultivars. 
common vetch (Vicia sativa L.) as winter cover crops, at densities of $50 \mathrm{~kg} \mathrm{ha}^{-1}$ and $30 \mathrm{~kg} \mathrm{ha}^{-1}$, respectively, seeded by broadcasting. Poultry litter was used as fertilizer during seeding $\left(5 \mathrm{t} \mathrm{ha}^{-1}\right)$ and the cover was fertilized with an additional dose of $5 \mathrm{t} \mathrm{ha}^{-1}$, at 15 days after emergence. Sulfocalcic ash was applied to manage pests and diseases, in addition to neem (Azadirachta indica A. Juss) oil, as an insect repellent. Weeding was carried out twice to control spontaneous weeds. Conventional management used the same densities and cover crops as the organic system, planted by broadcast seeding. Soluble NPK (5-25-25) mineral fertilizer was used at seeding $\left(400 \mathrm{~kg} \mathrm{ha}^{-1}\right)$ and, after plant emergence, the cover crop was fertilized with $\mathrm{N}$ from urea (45-00-00), at a dose of $80 \mathrm{~kg} \mathrm{ha}^{-1}$, divided into two applications, at the development stages V3 and V4.

Seeds, which were collected manually, had a moisture content of $12 \%$, and plants were pulled out individually. After removal, the plants from the two central rows of each plot (useful area) were placed in raffia bags and threshed by hand with the help of a wooden stick. Seeds from the study area of each plot were packed in bags and taken to the laboratory. After harvest, the seeds were combined as it follows: $500 \mathrm{~g}$ of seeds from plants of the central portion of each block were separated, totaling $1,500 \mathrm{~g}$, and mixed to obtain a compound sample. An average sample of $600 \mathrm{~g}$ was removed to obtain working samples to conduct the different tests (Brasil 2009). The average sample was kept in a dry and cool chamber until evaluations. The tests were performed shortly after harvest, in both seasons.

The seed physiological characteristics were assessed after harvest, by determining the germination percentage and seedling length after germination, and vigor by using the following tests: accelerated aging, seedling length after accelerated aging, electrical conductivity, seedling field emergence, cold test and seedling length after cold stress.

The viability test was conducted with a roll of germitest paper, moistened in distilled water at a ratio of 2.5 times the mass of dry paper, with four repetitions of 50 seeds. The rolls containing the seeds remained in a germinator, in the vertical position, for 5 days, at a temperature of $25^{\circ} \mathrm{C}$ (Brasil 2009). The counting of germinated seeds and measuring of seedling length were carried out at 5 days after starting the test.
The accelerated aging test was conducted according to Marcos Filho (1987), with four repetitions of 50 seeds, distributed on the stainlesssteel screen attached to the interior of the "gerbox ${ }^{\circledR}$ " plastic box containing $40 \mathrm{~mL}$ of distilled water. The boxes were covered, sealed with parafilm ${ }^{\circledR}$ and stored in a chamber at $42^{\circ} \mathrm{C}$, for $72 \mathrm{~h}$. The seeds were then distributed on germitest paper as in the germination test and, after 5 days, the germination percentage and seedling length were determined as measures of vigor.

The electrical conductivity test was performed with four repetitions of 50 seeds with known mass, packed in plastic recipients containing $75 \mathrm{~mL}$ of ultrapure water (MilliQ), at $25^{\circ} \mathrm{C}$, for $14 \mathrm{~h}$. After $14 \mathrm{~h}$, conductivity readings were taken (Marte MB-11P) and results expressed in $\mu \mathrm{S} \mathrm{cm}^{-1} \mathrm{~g}^{-1}$ of seed (Vieira \& Carvalho 1994).

Field emergence was evaluated with three repetitions of 240 seeds, distributed into plots with four rows with four meters long and 15 seeds per meter. Planting depth was approximately $0.03 \mathrm{~m}$ and spacing between rows $0.5 \mathrm{~m}$. Countings were done at 10 days after planting, at which time the percentage of emerged seedlings was determined (Popinigis 1985).

Seedling length was measured after the germination percentage, accelerated aging and cold tests were performed. At 5 days, 20 normal seedlings from each repetition were measured with a ruler. The average was calculated and the results expressed in centimeters.

The cold test was carried out with four repetitions of 50 seeds on two sheets of germitest paper covered by a third sheet, rolled up and kept in plastic sacks at $10^{\circ} \mathrm{C}$, for 5 days. The sacks were then opened, the germination test performed and seedling length measured (Barros et al. 1999). The results were expressed in percentage of normal seedlings.

The Genes software (Cruz 2006) was used for statistical analyses, applying the F-test for analysis of joint variance and the Scott-Knott test at $5 \%$ to compare the means for accessions in each growing system. To meet the theoretical assumptions implicit in the test, the germination percentage and germination percentage after accelerated aging were transformed, raising the power of their unit values to $1 / 2$, to obtain the inverse sine function (arcsine transformation), as suggested by descriptive data analysis. The results are presented in the original scales of these variables. 
The sum of ranks index proposed by Mulamba \& Mock(1978)wasusedtoidentifythesuperioraccessions, based on the simultaneous selection of the traits assessed. This consists of classifying accessions in order, according to the classes of each trait assessed. After this classification, the scores of the various traits of each accession were added up, with the lowest value indicating a more favorable combination of physiological seed quality traits and the highest an unfavorable combination with traits exhibiting less than desirable values. The sum of ranks index was associated with the Scott-Knott clustering method to characterize the accessions, in terms of physiological seed quality.

\section{RESULTS AND DISCUSSION}

The joint analysis of variance (using the F-test) of the eight traits assessed to determine the physiological seed quality showed a significant simple effect of the common bean accessions, which indicates sufficient diversity to categorize accessions based on physiological seed quality. No significant interaction was found for any of the variables between common bean accessions and years of growing. Thus, the comparison among accessions was performed with the average of the data from the two years of cultivation.

The results for accession characterization according to seed viability, using the germination test (Table 2), made it possible to separate accessions into four classes in both farming systems, highlighting BAF 75, BAF 81, BAF 112, BAF 42, BAF 13, BAF 55 and BAF 84 with germination percentages above $90 \%$ and $86 \%$ in the organic and conventional systems, respectively. Maia et al. (2011), with 94 bean breeding lines from the germplasm bank of the Universidade Federal de Lavras, also found variability in the lines, with respect to seed germination and seedling emergence.

Table 2. Germination percentage, vigor according to seedling length after the germination test and seedling vigor according to field emergence of landrace and commercial common bean accessions grown under organic and conventional systems.

\begin{tabular}{|c|c|c|c|c|c|c|}
\hline \multirow{2}{*}{ Accession } & \multicolumn{2}{|c|}{ Germination (\%) } & \multicolumn{2}{|c|}{ Seedling length germination $(\mathrm{cm})$} & \multicolumn{2}{|c|}{ Field emergence $(\%)$} \\
\hline & Organic & Conventional & Organic & Conventional & Organic & Conventional \\
\hline BAF 3 & $66 \mathrm{~d}$ & $73 \mathrm{~d}$ & $12.9 \mathrm{~d}$ & $16.9 \mathrm{a}$ & $70 \mathrm{~b}$ & $69 \mathrm{~b}$ \\
\hline BAF 4 & $72 \mathrm{c}$ & $69 \mathrm{~d}$ & $11.7 \mathrm{e}$ & $12.0 \mathrm{~d}$ & $59 \mathrm{~d}$ & $65 \mathrm{c}$ \\
\hline BAF 7 & $67 \mathrm{~d}$ & $78 \mathrm{c}$ & $13.2 \mathrm{~d}$ & $13.9 \mathrm{c}$ & $49 \mathrm{e}$ & $71 \mathrm{~b}$ \\
\hline BAF 13 & $90 \mathrm{a}$ & $87 \mathrm{~b}$ & $15.1 \mathrm{c}$ & $15.6 \mathrm{~b}$ & $71 \mathrm{~b}$ & 79 a \\
\hline BAF 23 & $87 \mathrm{~b}$ & $87 \mathrm{~b}$ & $14.9 \mathrm{c}$ & $13.9 \mathrm{c}$ & $63 \mathrm{c}$ & $70 \mathrm{~b}$ \\
\hline BAF 36 & $80 \mathrm{~b}$ & $88 \mathrm{~b}$ & $16.9 \mathrm{~b}$ & $16.7 \mathrm{a}$ & $74 \mathrm{~b}$ & 79 a \\
\hline BAF 42 & $91 \mathrm{a}$ & $88 \mathrm{~b}$ & $16.8 \mathrm{~b}$ & $16.9 \mathrm{a}$ & $73 \mathrm{~b}$ & $76 \mathrm{~b}$ \\
\hline BAF 44 & $68 \mathrm{~d}$ & $81 \mathrm{c}$ & $13.4 \mathrm{~d}$ & $16.9 \mathrm{a}$ & $58 \mathrm{~d}$ & $46 \mathrm{~d}$ \\
\hline BAF 46 & $78 \mathrm{c}$ & $85 \mathrm{c}$ & $13.9 \mathrm{~d}$ & $14.8 \mathrm{c}$ & $61 \mathrm{c}$ & $74 \mathrm{~b}$ \\
\hline BAF 47 & $74 \mathrm{c}$ & $82 \mathrm{c}$ & $13.9 \mathrm{~d}$ & $15.2 \mathrm{~b}$ & $63 \mathrm{c}$ & $60 \mathrm{c}$ \\
\hline BAF 50 & $83 \mathrm{~b}$ & $79 \mathrm{c}$ & $14.5 \mathrm{~d}$ & $15.4 \mathrm{~b}$ & $74 \mathrm{~b}$ & $57 \mathrm{c}$ \\
\hline BAF 55 & $90 \mathrm{a}$ & $92 \mathrm{~b}$ & $18.8 \mathrm{a}$ & $17.9 \mathrm{a}$ & $63 \mathrm{c}$ & $74 \mathrm{~b}$ \\
\hline BAF 57 & $64 \mathrm{~d}$ & $80 \mathrm{c}$ & $13.2 \mathrm{~d}$ & $15.6 \mathrm{~b}$ & $69 \mathrm{~b}$ & $71 \mathrm{~b}$ \\
\hline BAF 60 & $84 \mathrm{~b}$ & $88 \mathrm{~b}$ & $16.5 \mathrm{~b}$ & $16.6 \mathrm{a}$ & $71 \mathrm{~b}$ & $76 \mathrm{a}$ \\
\hline BAF 68 & $71 \mathrm{~d}$ & $68 \mathrm{~d}$ & $13.1 \mathrm{~d}$ & $12.7 \mathrm{~d}$ & $64 \mathrm{c}$ & $66 \mathrm{c}$ \\
\hline BAF 75 & $93 \mathrm{a}$ & $97 \mathrm{a}$ & $16.7 \mathrm{~b}$ & $17.5 \mathrm{a}$ & 88 a & 80 a \\
\hline BAF 81 & $92 \mathrm{a}$ & $97 \mathrm{a}$ & $16.7 \mathrm{~b}$ & $17.9 \mathrm{a}$ & 86 a & $75 \mathrm{~b}$ \\
\hline BAF 84 & $90 \mathrm{a}$ & $96 \mathrm{a}$ & $17.7 \mathrm{a}$ & $17.5 \mathrm{a}$ & 82 a & $71 \mathrm{~b}$ \\
\hline BAF 97 & $81 \mathrm{~b}$ & $89 \mathrm{~b}$ & $12.4 \mathrm{~d}$ & $14.9 \mathrm{c}$ & $59 \mathrm{~d}$ & $73 \mathrm{~b}$ \\
\hline BAF 102 & $79 \mathrm{c}$ & $76 \mathrm{~d}$ & $15.1 \mathrm{c}$ & $14.8 \mathrm{c}$ & $78 \mathrm{~b}$ & $62 \mathrm{c}$ \\
\hline BAF 108 & $67 \mathrm{~d}$ & $73 \mathrm{~d}$ & $14.3 \mathrm{~d}$ & $14.3 \mathrm{c}$ & $57 \mathrm{~d}$ & $58 \mathrm{c}$ \\
\hline BAF 110 & $84 \mathrm{~b}$ & $90 \mathrm{~b}$ & $15.8 \mathrm{c}$ & $17.1 \mathrm{a}$ & $65 \mathrm{c}$ & 80 a \\
\hline BAF 112 & $92 \mathrm{a}$ & $86 \mathrm{~b}$ & $15.4 \mathrm{c}$ & $16.5 \mathrm{a}$ & $71 \mathrm{~b}$ & $66 \mathrm{c}$ \\
\hline BAF 115 & $87 \mathrm{~b}$ & $82 \mathrm{c}$ & $16.3 \mathrm{~b}$ & $16.1 \mathrm{~b}$ & $73 \mathrm{~b}$ & $60 \mathrm{c}$ \\
\hline BAF 120 & $76 \mathrm{c}$ & $76 \mathrm{~d}$ & $9.6 \mathrm{f}$ & $10.8 \mathrm{~d}$ & $59 \mathrm{~d}$ & $62 \mathrm{c}$ \\
\hline BAF 121 & $88 \mathrm{~b}$ & 89 b & $16.1 \mathrm{c}$ & $16.6 \mathrm{a}$ & $76 \mathrm{~b}$ & $74 \mathrm{~b}$ \\
\hline
\end{tabular}

$\mathrm{BAF}=$ number at the UDESC active germplasm bank collection, in the Santa Catarina state, Brazil. Means followed by the same lower case letter in each column belong to the same class, according to the Scott-Knott test at $5 \%$. 
The field emergence results (Table 2) demonstrated a wide variation, where the percentage of emerged plants ranged from $49 \%$ to $88 \%$ in the organic system and from $46 \%$ to $80 \%$ under conventional management. In the organic system, BAF 75, BAF 81 and BAF 84 exhibited $82 \%$ of field emergence, while BAF 75 and BAF 110 showed $80 \%$.

The seed vigor results according to the seedling length after the germination test showed a significant diversity, separating accessions into six classes in the organic system and four in the conventional system, allowing the categorization of the most vigorous seeds. BAF 55 and BAF 84 were the most vigorous under organic management, with seedling length of more than $17 \mathrm{~cm}$. BAF 55, BAF 81, BAF 84, BAF 75, BAF 110, BAF 42, BAF 44, BAF 3, BAF 36, BAF 60, BAF 121 and BAF 122 were more vigorous after the germination test in the conventional system, with seedling lengths greater than $16.5 \mathrm{~cm}$ (Table 2).
The vigor test according to accelerated aging (Table 3) of the seeds produced in the organic system showed that BAF 81, BAF 75, BAF 13, BAF 84, BAF 36, BAF 57, BAF 60, BAF 42, BAF 110, BAF 115, BAF 97, BAF 112, BAF 55, BAF 121, BAF 46 and BAF 108 were the most vigorous, with results between $77 \%$ and $93 \%$. With respect to the seeds produced in the conventional system, BAF 81 , BAF 84, BAF 75, BAF 110 and BAF 55 were the most vigorous under organic management. The results divided the accessions into two classes in the organic system and three in the conventional one. Bertolin et al. (2011) analyzed the effects of temperatures and exposure time of six bean accessions to accelerated aging and found genetic diversity as a response to the vigor test according to aging, at different temperatures and exposure times. According to Krzyzanowski et al. (1982), the accelerated aging test is effective in assessing bean seed vigor, making it possible to observe diversity through this characteristic.

Table 3. Seed vigor according to accelerated aging, cold stress and electrical conductivity of landrace and commercial common bean accessions grown under organic and conventional systems.

\begin{tabular}{|c|c|c|c|c|c|c|}
\hline \multirow{2}{*}{ Accession } & \multicolumn{2}{|c|}{ Accelerated aging (\%) } & \multicolumn{2}{|c|}{ Cold test $(\%)$} & \multicolumn{2}{|c|}{ Electrical conductivity $\left(\mu \mathrm{S} \mathrm{cm}^{-1} \mathrm{~g}^{-1}\right)$} \\
\hline & Organic & Conventional & Organic & Conventional & Organic & Conventional \\
\hline BAF 3 & $68 \mathrm{~b}$ & $64 \mathrm{c}$ & $70 \mathrm{c}$ & $77 \mathrm{~b}$ & $25.6 \mathrm{c}$ & $27.8 \mathrm{~d}$ \\
\hline BAF 4 & $70 \mathrm{~b}$ & $53 \mathrm{c}$ & $64 \mathrm{~d}$ & $77 \mathrm{~b}$ & $27.1 \mathrm{c}$ & $53.0 \mathrm{~b}$ \\
\hline BAF 7 & $69 \mathrm{~b}$ & $77 \mathrm{~b}$ & $62 \mathrm{~d}$ & $66 \mathrm{~d}$ & $31.6 \mathrm{c}$ & $41.2 \mathrm{~b}$ \\
\hline BAF 13 & 88 a & $79 \mathrm{~b}$ & $84 \mathrm{~b}$ & $90 \mathrm{a}$ & $36.5 \mathrm{~b}$ & $62.5 \mathrm{a}$ \\
\hline BAF 23 & $75 \mathrm{~b}$ & $77 \mathrm{~b}$ & $69 \mathrm{c}$ & $75 \mathrm{c}$ & 52.7 a & $41.7 \mathrm{~b}$ \\
\hline BAF 36 & 85 a & $79 \mathrm{~b}$ & $71 \mathrm{c}$ & 83 a & $49.5 \mathrm{a}$ & 50.8 a \\
\hline BAF 42 & 83 a & $67 \mathrm{c}$ & $88 \mathrm{~b}$ & 89 a & $38.1 \mathrm{~b}$ & $61.6 \mathrm{a}$ \\
\hline BAF 44 & $70 \mathrm{~b}$ & $59 \mathrm{c}$ & $65 \mathrm{~d}$ & $59 \mathrm{~d}$ & $21.5 \mathrm{~d}$ & $34.1 \mathrm{c}$ \\
\hline BAF 46 & 79 a & $67 \mathrm{c}$ & $73 \mathrm{c}$ & $81 \mathrm{~b}$ & $33.7 \mathrm{c}$ & $47.7 \mathrm{a}$ \\
\hline BAF 47 & $69 \mathrm{~b}$ & $80 \mathrm{~b}$ & $65 \mathrm{~d}$ & $73 \mathrm{c}$ & $43.6 \mathrm{~b}$ & $53.9 \mathrm{a}$ \\
\hline BAF 50 & $76 \mathrm{~b}$ & $68 \mathrm{c}$ & $84 \mathrm{~b}$ & $74 \mathrm{c}$ & $40.8 \mathrm{~b}$ & $44.9 \mathrm{~b}$ \\
\hline BAF 55 & 80 a & 89 a & $76 \mathrm{c}$ & $81 \mathrm{~b}$ & $63.0 \mathrm{a}$ & $53.0 \mathrm{~b}$ \\
\hline BAF 57 & $85 \mathrm{a}$ & $78 \mathrm{~b}$ & $74 \mathrm{c}$ & $77 \mathrm{~b}$ & $41.0 \mathrm{~b}$ & $61.5 \mathrm{a}$ \\
\hline BAF 60 & $84 \mathrm{a}$ & $84 \mathrm{~b}$ & $75 \mathrm{c}$ & $81 \mathrm{~b}$ & $44.5 \mathrm{~b}$ & $56.2 \mathrm{a}$ \\
\hline BAF 68 & $72 \mathrm{~b}$ & $72 \mathrm{c}$ & $62 \mathrm{~d}$ & $75 \mathrm{c}$ & $24.9 \mathrm{c}$ & $40.3 \mathrm{~b}$ \\
\hline BAF 75 & 89 a & $90 \mathrm{a}$ & $91 \mathrm{a}$ & $87 \mathrm{a}$ & $48.6 \mathrm{a}$ & $60.7 \mathrm{a}$ \\
\hline BAF 81 & $93 \mathrm{a}$ & $95 \mathrm{a}$ & $96 \mathrm{a}$ & 86 a & $49.1 \mathrm{a}$ & $64.2 \mathrm{a}$ \\
\hline BAF 84 & $87 \mathrm{a}$ & $93 \mathrm{a}$ & $84 \mathrm{~b}$ & $85 \mathrm{a}$ & $57.5 \mathrm{a}$ & $68.3 \mathrm{a}$ \\
\hline BAF 97 & 82 a & $78 \mathrm{~b}$ & $71 \mathrm{c}$ & $84 \mathrm{a}$ & $39.0 \mathrm{~b}$ & $47.4 \mathrm{~b}$ \\
\hline BAF 102 & $76 \mathrm{~b}$ & $71 \mathrm{c}$ & $77 \mathrm{c}$ & $67 \mathrm{~d}$ & $45.4 \mathrm{a}$ & $74.4 \mathrm{a}$ \\
\hline BAF 108 & $77 \mathrm{a}$ & $69 \mathrm{c}$ & $66 \mathrm{~d}$ & $79 \mathrm{~b}$ & $61.0 \mathrm{a}$ & $41.5 \mathrm{~b}$ \\
\hline BAF 110 & 83 a & 89 a & $76 \mathrm{c}$ & $83 \mathrm{a}$ & $52.7 \mathrm{a}$ & $54.9 \mathrm{a}$ \\
\hline BAF 112 & 82 a & $78 \mathrm{~b}$ & $84 \mathrm{~b}$ & $78 \mathrm{~b}$ & $50.3 \mathrm{a}$ & $81.0 \mathrm{a}$ \\
\hline BAF 115 & 83 a & $78 \mathrm{~b}$ & $87 \mathrm{~b}$ & $72 \mathrm{c}$ & $46.9 \mathrm{a}$ & $40.8 \mathrm{~b}$ \\
\hline BAF 120 & $65 \mathrm{~b}$ & $68 \mathrm{c}$ & $64 \mathrm{~d}$ & $65 \mathrm{~d}$ & $41.1 \mathrm{~b}$ & 56.6 a \\
\hline BAF 121 & 80 a & $80 \mathrm{~b}$ & $74 \mathrm{c}$ & $83 \mathrm{a}$ & $63.5 \mathrm{a}$ & $60.7 \mathrm{a}$ \\
\hline
\end{tabular}

$\mathrm{BAF}=$ number at the UDESC active germplasm bank collection, in the Santa Catarina state, Brazil. Means followed by the same lower case letter in each column belong to the same class, according to the Scott-Knott test at $5 \%$. 
Assessing the vigor of seeds exposed to cold made it possible to separate the accessions into four classes in the two farming systems. In the organic system, BAF 81 and BAF 75, followed by BAF 42, BAF 115, BAF 84, BAF 13, BAF 112 and BAF 50 , obtained results above $84 \%$. Accessions BAF 13, BAF 42, BAF 75, BAF 81, BAF 84, BAF 97 , BAF 110, BAF 121 and BAF 36, in the conventional system, exhibited results greater than $83 \%$ (Table 3 ). Similarly to the accelerated aging test, the cold test, according to AOSA (1983), has been highly efficient in indicating the field emergence potential of seeds. The cold vigor test is used to assess the seed germination performance in low temperature conditions, during the field emergence period, what can be observed in early planting in Southern Brazil.

The results observed in the present study, in terms of seed vigor using the electrical conductivity test (Table 3), divided accessions from both farming systems into four classes. BAF 44, BAF 68, BAF 3, BAF 4, BAF 7 and BAF 46 showed the lowest values (21.5-33.7 $\left.\mu \mathrm{S} \mathrm{cm}^{-1} \mathrm{~g}^{-1}\right)$ in the organic system, and, in the conventional system, BAF 3, followed by BAF 4, displayed the lowest electrical conductivity, ranging from $27.8 \mu \mathrm{S} \mathrm{cm}^{-1} \mathrm{~g}^{-1}$ to $34.1 \mu \mathrm{S} \mathrm{cm}^{-1} \mathrm{~g}^{-1}$.

According to Marcos Filho (2005), the electrical conductivity test has shown to be efficient in assessing the seed vigor of various species. However, in contrast to the literature, when the electrical conductivity results observed in this study are compared with those from the other vigor tests, BAF 84 exhibited one of the worst electrical conductivity results $\left(68.3 \mu \mathrm{S} \mathrm{cm} \mathrm{cm}^{-1} \mathrm{~g}^{-1}\right)$, but also satisfactory vigor for accelerated aging $(93 \%)$ and the cold test $(85 \%)$. BAF 44 , with favorable electrical conductivity $\left(21.5 \mu \mathrm{S} \mathrm{cm}^{-1} \mathrm{~g}^{-1}\right)$, obtained unfavorable results in the other vigor tests. Contradictory seed vigor results, according to the electrical conductivity and accelerated aging tests, were also recorded for seeds from soybean accessions (Santorum et al. 2013).

The accessions were separated into four seedling length classes after the accelerated aging test, in both systems, and into three and five classes after the cold test in the organic and conventional systems, respectively (Table 4).

The measure of seed vigor according to seedling length after accelerated aging ranged from $11.1 \mathrm{~cm}$ to $17.7 \mathrm{~cm}$ and $10.0 \mathrm{~cm}$ to $18.3 \mathrm{~cm}$, and after the cold tests from $9.1 \mathrm{~cm}$ to $15.1 \mathrm{~cm}$ and $9.9 \mathrm{~cm}$ to
$17.7 \mathrm{~cm}$, respectively in the organic and conventional systems (Table 4). With respect to seedling vigor under organic management after accelerated aging, BAF 84, BAF 81, BAF 55, BAF 75 and BAF 112 stood out, while, in the conventional system, BAF 55, BAF 81, BAF 60, BAF 84, BAF 7, BAF 13, BAF 121 and BAF 115 were the most vigorous ones. After accelerated aging, BAF 84, BAF 81 and BAF 55 exhibited a good seedling vigor in both farming systems (Table 4). After the seedlings were submitted to cold stress in the organic system, BAF 55, BAF 81, BAF 110, BAF 3, BAF 75, BAF 60, BAF 84, BAF 121, BAF 112, BAF 42, BAF 46, BAF 23, BAF 13, BAF 36, BAF 50, BAF 68, BAF 97, BAF 44 and BAF 108 displayed the best vigor, while BAF 84, BAF 55, BAF 121 and BAF 112 performed best under the organic system (Table 4).

The sum of ranks index proposed by Mulamba \& Mock (1978) for the eight traits of

Table 4. Seed vigor according to seedling length after accelerated aging and cold stress of landrace and commercial common bean accessions grown under organic and conventional systems.

\begin{tabular}{|c|c|c|c|c|}
\hline \multirow[t]{2}{*}{ Accession } & \multicolumn{2}{|c|}{$\begin{array}{l}\text { Seedling length after } \\
\text { accelerated aging }(\mathrm{cm})\end{array}$} & \multicolumn{2}{|c|}{$\begin{array}{l}\text { Seedling length } \\
\text { after cold test }(\mathrm{cm})\end{array}$} \\
\hline & Organic & Conventional & Organic & Conventional \\
\hline BAF 3 & $12.8 \mathrm{c}$ & $13.8 \mathrm{c}$ & $14.1 \mathrm{a}$ & $14.3 \mathrm{~b}$ \\
\hline BAF 4 & $11.4 \mathrm{~d}$ & $10.0 \mathrm{~d}$ & $11.4 \mathrm{~b}$ & $12.1 \mathrm{c}$ \\
\hline BAF 7 & $13.4 \mathrm{c}$ & $17.0 \mathrm{a}$ & $12.2 \mathrm{~b}$ & $12.4 \mathrm{c}$ \\
\hline BAF 13 & $13.7 \mathrm{c}$ & $16.9 \mathrm{a}$ & $13.0 \mathrm{a}$ & $15.2 \mathrm{~b}$ \\
\hline BAF 23 & $14.6 \mathrm{~b}$ & $14.4 \mathrm{c}$ & $13.2 \mathrm{a}$ & $12.6 \mathrm{c}$ \\
\hline BAF 36 & $14.2 \mathrm{c}$ & $15.6 \mathrm{~b}$ & $12.9 \mathrm{a}$ & $14.5 \mathrm{~b}$ \\
\hline BAF 42 & $15.4 \mathrm{~b}$ & $15.2 \mathrm{~b}$ & $13.4 \mathrm{a}$ & $15.2 \mathrm{~b}$ \\
\hline BAF 44 & $14.9 \mathrm{~b}$ & $14.7 \mathrm{c}$ & $12.7 \mathrm{a}$ & $12.9 \mathrm{c}$ \\
\hline BAF 46 & $13.2 \mathrm{c}$ & $14.0 \mathrm{c}$ & $13.4 \mathrm{a}$ & $14.1 \mathrm{~b}$ \\
\hline BAF 47 & $13.7 \mathrm{c}$ & $14.4 \mathrm{c}$ & $11.8 \mathrm{~b}$ & $12.1 \mathrm{c}$ \\
\hline BAF 50 & $13.3 \mathrm{c}$ & $14.7 \mathrm{c}$ & $12.8 \mathrm{a}$ & $13.5 \mathrm{c}$ \\
\hline BAF 55 & $16.5 \mathrm{a}$ & $18.3 \mathrm{a}$ & $15.1 \mathrm{a}$ & $17.6 \mathrm{a}$ \\
\hline BAF 57 & $13.7 \mathrm{c}$ & $14.9 \mathrm{c}$ & $12.3 \mathrm{~b}$ & $15.0 \mathrm{~b}$ \\
\hline BAF 60 & $15.5 \mathrm{~b}$ & $17.2 \mathrm{a}$ & $13.8 \mathrm{a}$ & $14.8 \mathrm{~b}$ \\
\hline BAF 68 & $12.6 \mathrm{c}$ & $13.4 \mathrm{c}$ & $12.8 \mathrm{a}$ & $11.3 \mathrm{~d}$ \\
\hline BAF 75 & $16.3 \mathrm{a}$ & $16.4 \mathrm{~b}$ & $13.9 \mathrm{a}$ & $15.7 \mathrm{~b}$ \\
\hline BAF 81 & $17.1 \mathrm{a}$ & $17.9 \mathrm{a}$ & $14.1 \mathrm{a}$ & $14.9 \mathrm{~b}$ \\
\hline BAF 84 & $17.7 \mathrm{a}$ & $17.0 \mathrm{a}$ & $13.8 \mathrm{a}$ & $17.7 \mathrm{a}$ \\
\hline BAF 97 & $13.3 \mathrm{c}$ & $13.3 \mathrm{c}$ & $12.8 \mathrm{a}$ & $12.5 \mathrm{c}$ \\
\hline BAF 102 & $14.7 \mathrm{~b}$ & $16.3 \mathrm{~b}$ & $11.8 \mathrm{~b}$ & $14.1 \mathrm{~b}$ \\
\hline BAF 108 & $14.3 \mathrm{c}$ & $16.0 \mathrm{~b}$ & $12.6 \mathrm{a}$ & $13.6 \mathrm{c}$ \\
\hline BAF 110 & $15.8 \mathrm{~b}$ & $16.0 \mathrm{~b}$ & $14.1 \mathrm{a}$ & $15.8 \mathrm{~b}$ \\
\hline BAF 112 & $16.1 \mathrm{a}$ & $15.6 \mathrm{~b}$ & $13.6 \mathrm{a}$ & $16.7 \mathrm{a}$ \\
\hline BAF 115 & $15.4 \mathrm{~b}$ & $16.6 \mathrm{a}$ & $11.3 \mathrm{~b}$ & $13.3 \mathrm{c}$ \\
\hline BAF 120 & $11.1 \mathrm{~d}$ & $10.6 \mathrm{~d}$ & $9.1 \mathrm{c}$ & $9.9 \mathrm{e}$ \\
\hline BAF 121 & $15.3 \mathrm{~b}$ & $16.8 \mathrm{a}$ & $13.7 \mathrm{a}$ & $17.1 \mathrm{a}$ \\
\hline
\end{tabular}


physiological seed quality studied under the organic system ranged from 34 to 179 for accessions BAF 81 and BAF 120, respectively (Figure 1a), and between 45 and 183 for BAF 75 and BAF 120, respectively, under the conventional system (Figure 1b).

The sum of ranks index (Mulamba \& Mock 1978) associated with the Scott-Knott clustering method classified the accessions analyzed into three classes under organic management, namely high, medium and low physiological seed quality (Figure 1a), and two classes under the conventional farming system, defined as high and medium/low physiological seed quality (Figure 1b).

BAF 81, BAF 75, BAF 84 and BAF 42 were classified as high physiological seed quality in the sum of ranks under the organic system, while BAF 112, BAF 13, BAF 60, BAF 55, BAF 115, BAF 110, BAF 121, BAF 36, BAF 50 and BAF 102 were defined as medium quality. BAF 46, BAF 23, BAF 57, BAF 3, BAF 97, BAF 44, BAF 68, BAF 47,
BAF 108, BAF 4, BAF 7 and BAF 120 exhibited the worst combination of seed viability and vigor traits, i.e., low physiological seed quality, under the organic farming system (Figure 1a).

BAF 75, BAF 55, BAF 81, BAF 110, BAF 84, BAF 121, BAF 60, BAF 13, BAF 36 and BAF 42 were classified as high physiological seed quality in the sum of ranks under conventional farming and BAF 97, BAF 112, BAF 115, BAF 57, BAF 3, BAF 46, BAF 7, BAF 23, BAF 108, BAF 47, BAF 44, BAF 50, BAF 102, BAF 68, BAF 4 and BAF 120 as medium/low quality (Figure $1 \mathrm{~b}$ ).

No differences in physiological seed quality were observed between the two farming systems. All the accessions included in the high quality category under the conventional system also belong to the high and medium quality categories under the organic system. The sum of ranks of these accessions under the organic system ranged from 34 to 96 (Figure 1a) and from 45 to 89 under conventional farming
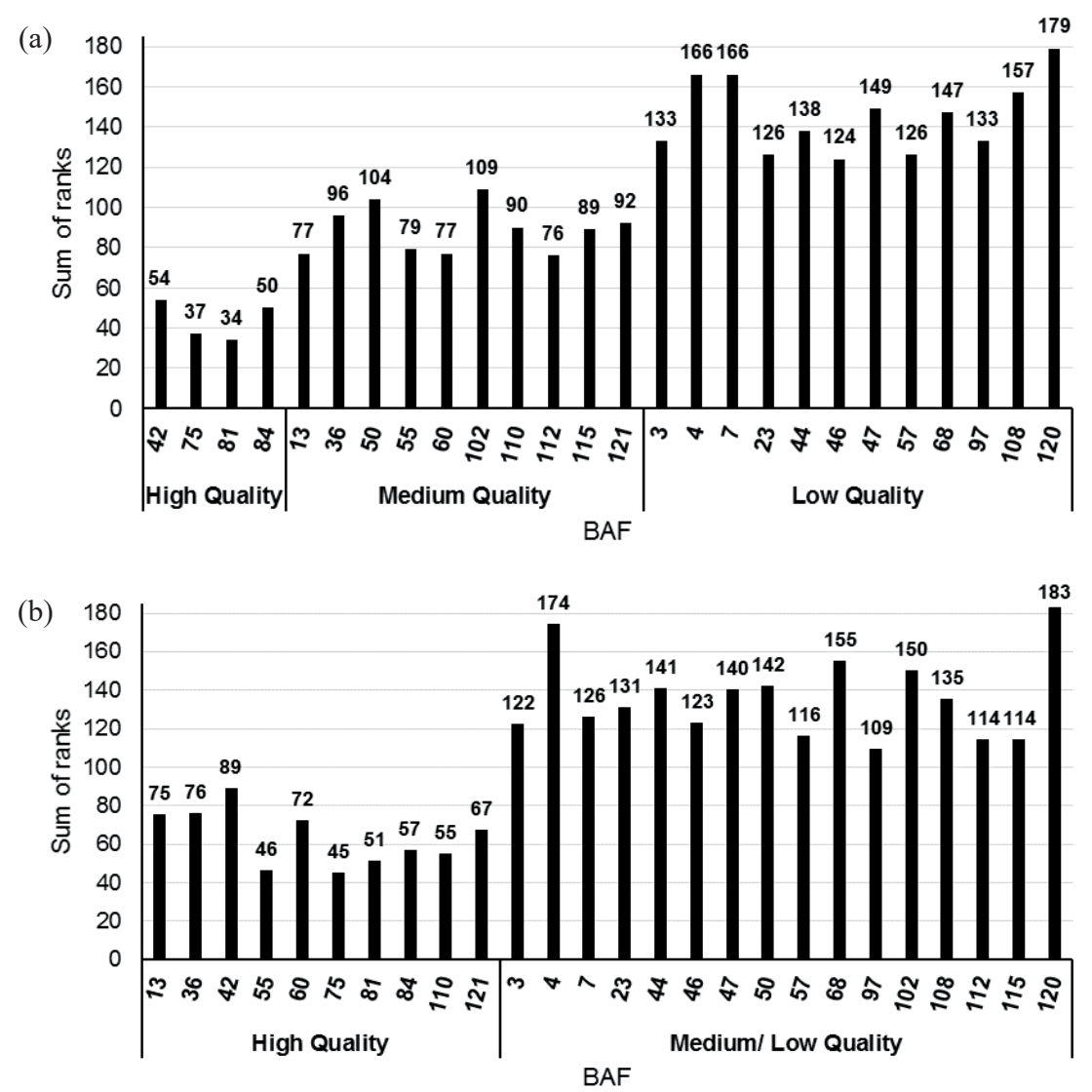

Figure 1. Sum of ranks proposed by Mulamba \& Mock (1978) and classified by the Scott-Knott clustering method of 26 landrace and commercial common bean accessions grown under organic (a) and conventional (b) system, considering the variables under study (sum of ranks groups: high quality, medium quality and low quality). BAF = number at the UDESC active germplasm bank collection, in the Santa Catarina state, Brazil. 
(Figure 1b). Individually, some accessions obtained a better result when grown organically, while others performed better under the conventional system.

High seed quality was observed for landrace common bean with different seed colors in both the organic and conventional crops, what can be used for multiplication and distribution to farmers.

In 2014, based on the results of public consultation, the mandatory period to use seeds from organic systems was revoked, given the scarcity of organic seeds that qualify for certification in the entire production chain (Brasil 2014). Pelwing et al. (2008) reported that the most frequent problem cited by farmers in maintaining landrace seeds is the difficulty in exchanging and obtaining seeds.

The multiplication and distribution of high quality landrace seeds may be an alternative to supply the demand for organic seeds. However, no accession should be ruled out for inferior seed quality, since they exhibit other important characteristics. As such, alternative management techniques should be found to achieve a better seed quality, as well as additional studies to improve storage conditions, in order to preserve the quality of seeds produced.

\section{CONCLUSIONS}

1. Accessions of common bean exhibit diversity in physiological seed quality, in terms of their viability and vigor;

2. No differences in physiological seed quality were observed between the organic and conventional farming systems;

3. The common bean accessions classification allowed to identify those with superior seed physiological quality (e.g. BAF 42, BAF 75, BAF 81 and BAF 84).

\section{REFERENCES}

ALTEMBURG, S. N. et al. Valorização de saberes locais para o desenvolvimento da agricultura familiar em rede de referência. Revista de la Facultad de Agronomía, v. 112, n. 1, p. 73-81, 2013.

ASSOCIATION OF OFFICIAL SEED ANALYSTS (AOSA). Seed vigour testing handbook. Whashington, DC: AOSA, 1983.

BARROS, A. S. R. et al. Teste de frio. In: Krzyzanowski, F. C.; VIEIRA, R. D.; FRANÇA NETO, J. B. Vigor de sementes: conceitos e testes. Londrina: Abrates, 1999. p. 1-15.

BERTOLIN, D. C.; SÁ, M. E.; MOREIRA, E. R. Parâmetros do teste de envelhecimento acelerado para determinação do vigor de sementes de feijão. Revista Brasileira de Sementes, v. 33, n. 1, p. 104-112, 2011.

BORDIN, L. C. et al. Diversidade genética para a padronização do tempo e percentual de hidratação preliminar ao teste de cocção de grãos de feijão. Ciência e Tecnologia de Alimentos, v. 30, n. 4, p. 890-896, 2010.

BRASIL. Instrução normativa $\mathrm{N}^{\circ} 17$, de 18 de junho de 2014. Altera o regulamento técnico para os sistemas orgânicos de produção. Diário Oficial da União, Brasília, DF, 2014. p. 32.

BRASIL. Instrução normativa $\mathrm{N}^{\circ}$ 64, de 18 de dezembro de 2008. Aprova o regulamento técnico para os sistemas orgânicos de produção animal e vegetal. Diário Oficial da União, Brasília, DF, 2008. p. 21.

BRASIL. Lei $n^{\circ} 10711$, de 05 de agosto de 2003. Dispõe sobre o Sistema Nacional de Sementes e Mudas e dá outras providências. Diário Oficial da União, Brasília, DF, 2003. Seção 1, p. 1.

BRASIL. Ministério da Agricultura, Pecuária e Abastecimento. Regras para análise de sementes. Brasília, DF: MAPA, 2009.

COELHO, C. M. M. et al. Capacidade de cocção de grãos de feijão em função do genótipo e da temperatura da água de hidratação. Ciência e Agrotecnologia, v. 32, n. 4, p. 1080-1086, 2008.

COELhO, C. M. M. et al. Características morfoagronômicas de cultivares crioulas de feijão-comum em dois anos de cultivo. Semina: Ciências Agrárias, v. 31, suppl., p. 1177-1186, 2010a.

COELHO, C. M. M. et al. Diversidade genética em acessos de feijão (Phaseolus vulgaris L.). Ciência Rural, v. 37, n. 5, p. 1241-1247, 2007.

COELho, C. M. M. et al. Potencial fisiológico em sementes de cultivares de feijão crioulo (Phaseolus vulgaris L.). Revista Brasileira de Sementes, v. 32, n. 3 p. 97-105, $2010 \mathrm{~b}$.

CRUZ, C. D. Programa Genes: biometria. Viçosa: Ed. UFV, 2006.

GLIESSMAN, S. R. Agroecologia: processos ecológicos em agricultura sustentável. Porto Alegre: UFRGS, 2000.

HENNING, F. A. et al. Composição química e mobilização de reservas em sementes de soja de alto e baixo vigor. Bragantia, v. 69, n. 3, p. 727-734, 2010. 
KRZYZANOWSKI, F. C. et al. O envelhecimento precoce na avaliação de lotes de sementes de feijoeiro. Revista Brasileira de Sementes, v. 4, n. 1, p. 45-48, 1982.

MAIA, L. G. S. et al. Variabilidade genética associada à germinação e vigor de sementes de linhagens de feijoeiro comum. Ciência e Agrotecnologia, v. 35, n. 2, p. 361-367, 2011.

MARCOS FILHO, J. Fisiologia de sementes de plantas cultivadas. Piracicaba: Fealq, 2005.

MARCOS FILHO, J.; CÍCERO, S. M.; SILVA, W. R. Avaliação da qualidade das sementes. Piracicaba: Fealq, 1987.

MICHELS, A. F. et al. Qualidade fisiológica de sementes de feijão crioulo produzidas no oeste e planalto catarinense. Revista Ciência Agronômica, v. 45, n. 3, p. 620-632, 2014.

MULAMBA, N. N.; MOCK, J. J. Improvement of yield potential of the method Eto Blanco maize (Zea mays L.) population by breeding for plant traits. Egyptian Journal of Genetics and Cytology, v. 7, n. 1, p. 40-51, 1978.

NEDEL, L. J. Fundamentos da qualidade de sementes. In: PESKE, S. T.; ROSENTHAL, M.; ROTA, G. Sementes: fundamentos científicos e tecnológicos. Pelotas: UFPel, 2003. p. $94-137$.

PELWING, A. B. et al. Sementes crioulas: o estado da arte no Rio Grande do Sul. Revista de Economia e Sociologia Rural, v. 46, n. 2, p. 391-420, 2008.
PENTEADO, S. R. Manual prático de agricultura orgânica: fundamentos e técnicas. 2. ed. Campinas: Ed. do Autor, 2010.

PEREIRA, T. et al. Diversidade no teor de nutrientes em grãos de feijão crioulo no Estado de Santa Catarina. Acta Scientiarum: Agronomy, v. 33, n. 3, p. 477-485, 2011.

PEREIRA, T. et al. Diversity in common bean landraces from South - Brazil. Acta Botanica Croatica, v. 68, n. 1, p. 79-92, 2009.

POPINIGIS, F. Fisiologia da semente. Brasília, DF: Agiplan, 1985.

RODRIGUES, L. S. et al. Divergência genética entre cultivares locais e cultivares melhoradas de feijão. Pesquisa Agropecuária Brasileira, v. 37, n. 9, p. 12751284, 2002.

SANTORUM, M. et al. Comparison of tests for the analysis of vigor and viability in soybean seeds and their relationship to field emergence. Acta Scientiarum: Agronomy, v. 35, n. 1, p. 83-92, 2013.

VIEIRA, R. D.; CARVALHO, N. M. Testes de vigor em sementes. Jaboticabal: Funep, 1994.

ZÍLIO, M. et al. The genotype and crop environment affect the technological quality of common beans grains. American-Eurasian Journal of Agricultural \& Environmental Sciences, v. 14, n. 3, p. 212-220, 2014. 